\title{
Analysis of leachate from solidified peat soil
}

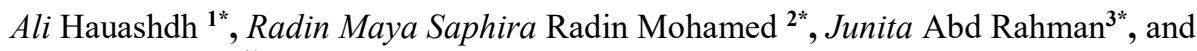 \\ Junaidah Jailani ${ }^{*}$ \\ ${ }^{1}$ Faculty of Civil and Environmental Engineering \\ ${ }^{2}$ Universiti Tun Hussein Onn Malaysia (UTHM), Johor, 86400 Malaysia
}

\begin{abstract}
Peat soil is very compressible where this characteristic is lead to an excessive settlement. Solidification of peat soil is a method to improve engineering properties of peat soil. Currently, solidification of peat soil is increasing, wherefore it is a critical need to study the environmental effects from solidified peat soil leachate due to solidification peat mixtures usually used materials of generation wastes from coal-fired electric power. The effect of leachate from solidified peat to the environment is one of the most important criteria that should be investigated. This study aims to investigate the environmental impacts of leachate from solidified peat affected by rainwater. In this study, solidification of hemic peat soil was done by mixing hemic peat soil with ordinary Portland cement (OPC), fly ash (FA) and bottom ash (BA). Leachate is the liquid that has percolated through a soil column outlets. Therefore, this study was to analysis the leachate from solidified hemic peat when it is saturated by rainwater in two different conditions, which are a dry and wet season by using physical model (soil column). The leachate samples were analyzed by using Ionic Chromatography (IC) and Inductively Coupled Plasma Mass Spectrometry (IC-MS). The anions concentration of leachate from solidified peat has increased for $\mathrm{Cl}^{-} \mathrm{SO}_{4}{ }^{2-}$ in wet condition as result rainwater inflow was increased during the wet condition, and the chemical composition of rainwater contains $\mathrm{Cl}^{-}$and $\mathrm{SO}_{4}{ }^{2-}$. The concentration of cations on the leachate from solidified peat has increased at $\mathrm{Fe}^{+2}$ and $\mathrm{Al}^{+3}$ in wet condition, which proven solidified peat has an effect on the leachate In comparison with leachate of non-solidified peat. The concentration of anions for $\mathrm{Cl}^{-}$and $\mathrm{SO}_{4}{ }^{2-}$ the leachate still consider in the normal range of groundwater concentration that classified as freshwater, but in case FA, BA, and OPC are used excessively in the mixture for solidifying peat in a wetland, leachate from solidified peat will effect on elements concentration of groundwater and land properties.
\end{abstract}

Keywords: Leachate, peat, solidified, environmental

\section{Introduction}

There is about 2.7 million ha of peat and organic soils in Malaysia. In Sarawak, peatlands are in abundance and Sarawak has the largest area of peat in the country, covering about 1.66 million ha and constituting $13 \%$ of the state [1]. Peat soil is an extremely soft soil and often referred to as challenging soil by engineers. Peat is a highly organic soil, which is partially 
decomposed or fully decomposed plant fragment with virtually no measurable strength [2]. Since this organic soil is a result from the suitable condition of a lake river, this peat soil would have a very high percentage in organic content that is made of carbon and usually occurs in the area of wetland condition [3]. Soil scientists define peat as a soil with organic content greater than $35 \%$ [4]. However, peat soil classification has been narrowed to three (3) classes: (1) fabric (fibrous; least decomposed with fiber content more than $67 \%$ ); (2) hemic (semi-fibrous; decomposed); (3) sapric (amorphous; most decomposed with fiber content less than $33 \%$ ) [7]. Peat mostly to cause settlement problems in construction and infrastructure development mainly comes from structures and highway constructions [5]. These problems can lead to building collapsed and road settlements [6]. The need for peat treatment is now increasing as modernization took place all over the world. A study of treated peat on effect to environment is a critical need to study and investigate the environmental impacts of solidified peat leachate because mixtures for solidified peat usually used materials come from generation wastes from coal-fired electric power, which need an investigation on how leachate from solidified peat will effect to environment. Major impacts are generally associated with changes in water chemistry and using ash as a soil addition can improve soil texture and water-holding capacity [14]. Solidification of peat soil could be solidified with cementitious materials (cement, lime, fly ash). The use of fly ash and bottom ash as materials in construction projects consuming large volumes of materials, such as highway embankment constructions [13]. Fly ash and bottom ash are the solid residual byproducts generated by coal-burning electric utilities. They are usually disposed of together as a waste in utility disposal sites with a typical distribution rate of $80 \%$ fly ash and $20 \%$ bottom ash [9]. The physical and chemical properties of coal ashes are dependent on the coal's geological origin, combustion conditions, the efficiency of particulate removal, and degree of weathering before final disposal [9]. However, this study focuses on the leachate from solidified peat effects to environment when solidified peat saturated by rainwater.

\section{Materials and Methods}

\subsection{Materials}

Raw hemic peat soil was collected from Kampung Medan Sari, Johor. Peat soil was tested according to von post scale when suspected hemic. Bottom ash and fly ash are collected from Tanjung Bin, power plant, Pontain, Johor. Fly ash and bottom ash is a waste of coal-fired electric power generation facilities. Variety of sizes owned by bottom ash was recorded, starting from aggregates to fine sand. Fly ash was oven dried to ensure moisture free then kept in a container. The cement was the first oven dried to ensure moisture free and kept in a tight container. The harvesting of rainwater simply involves the collection of water from surfaces and subsequently storing.

\subsection{Mixing}

Fly ash, bottom ash, and OPC were mixed with hemic peat soil. The mixing is done by using a mixer machine for 10 minutes until all OPC, FA, and BA was fully mixed with hemic peat soil. The mixture consists of OPC with an equal amount of dry mass of the peat and combination of the peat fiber and bottom ash in the range of $23-34 \%$ of the total mixture. Additions of $25 \%$ fly ash of the total mass of binder. Binder is a combination of OPC, fly and bottom ash. The mixing formulation is based on Abd Rahman's formula [8]. Samples of solidified peat are curing for 28 days in dry place. The mixture of the samples prepared is as represents in Table 1. 
Table 1. Mixture proportion.

\begin{tabular}{|c|c|c|c|c|c|}
\hline Type & $\begin{array}{c}\text { Hemic peat } \\
\text { soil }\end{array}$ & FA & BA & OPC & $\begin{array}{c}\text { The total mass } \\
\text { of the mixture }\end{array}$ \\
\hline Mass (g) & 800 & 176 & 232 & 104 & 1312 \\
\hline
\end{tabular}

\subsection{Physical Model}

First stage hemic peat without solidified was placed on the soil column and rainwater was fill up on the top of soil column after that leachate collected from the outlets as shown in Figure 1. The second stage, samples of solidified hemic peat after curing 28 days were placed on the soil column and leachate was collected. However, the soil column has four outlets with different depth. The leachate of soil column was collected from the four outlets in four conical flasks for two conditions (dry and wet). Rainwater volume was for the wet season is $1500 \mathrm{ml}$ and $50 \mathrm{ml}$ for the dry season to simulate the environmental effects. The leachate samples that were collected from soil column outlets are analyzed by using IC and IC-MS instruments.
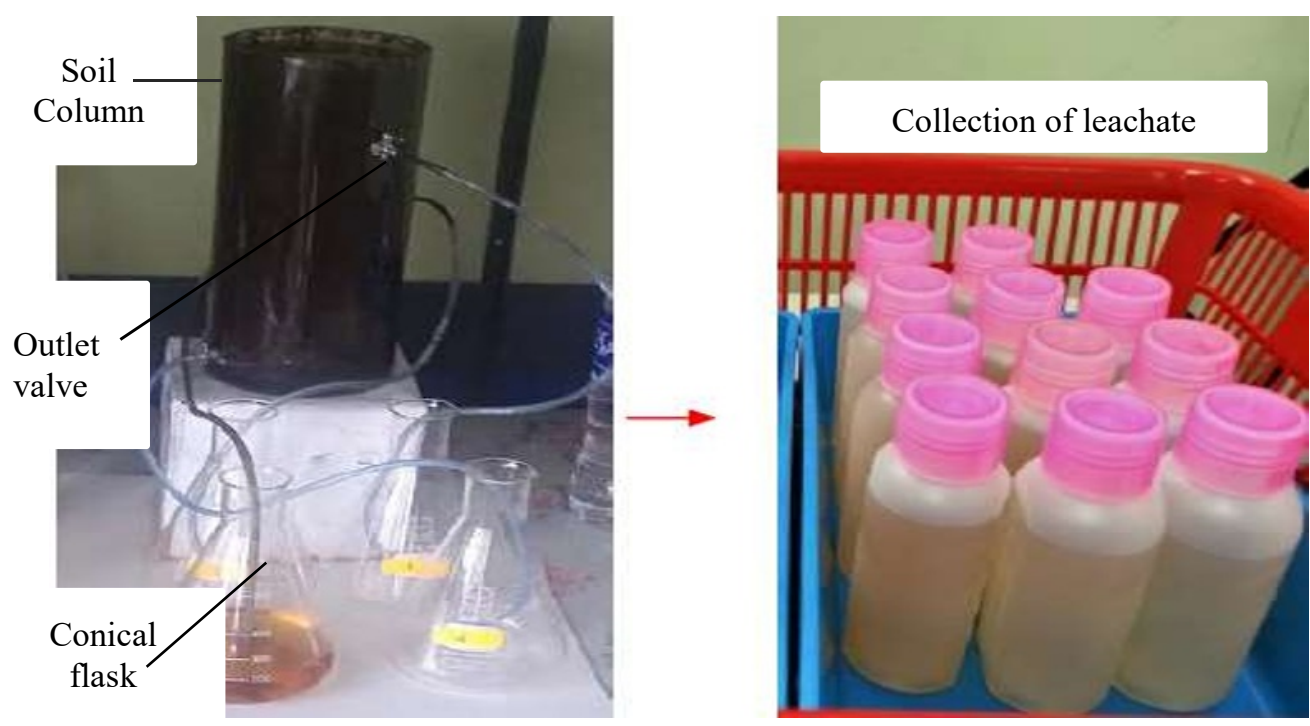

Fig. 1. Work process of the soil column.

\section{Results and Discussion}

\subsection{XRF Analysis}

$\mathrm{X}$-Ray Fluorescence (XRF) is used to determine the chemical composition of the materials. Figure 2 shows the results of XRF analysis of the solidification agents (FA, BA, and OPC) and hemic peat soil where these materials are the mixture of solidified peat soil. The XRF analysis was done for these materials before mixing. However, hemic peat is contained carbon represents in $89.9 \%$, this result obtained by organic content test and the remaining of hemic is chemical composition analysis by using XRF. The highest mass percentage in hemic peat is $\mathrm{CaO}, \mathrm{Fe}_{2} \mathrm{O}_{3}, \mathrm{SO}_{3}$, and $\mathrm{Al}_{2} \mathrm{O}_{3}$ with a value of mass percentage $37.40 \%, 21.40 \%$, $6.97 \%$, and $4.62 \%$ respectively. The highest concentration of elements properties in OPC is $\mathrm{CaO}$ with a value of $54.10 \%$. $\mathrm{CaO}$ is one of the major oxides in composing ordinary Portland 
cement because raw limestone is an essential material that used to crush in (OPC) production process and $\mathrm{CaO}$ is the main chemical composition in limestone. Bottom ash and fly ash content high concentration of $\mathrm{SiO}_{2}$ with a value of $44.40 \%$ and $48.00 \%$ respectively. The concentration of $\mathrm{Al}_{2} \mathrm{O}_{3}$ was $9.52 \%$ in OPC, $27.50 \%$ in FA and $26.60 \%$ in BA. The percentage of the composition depends on the type of source that produces fly ash and bottom ash, the chemical content of the coal used by the power plants may have changed [9]. Therefore, as this study aims to analyze the leachate from solidified peat, it is required for analyzing the chemical composition of materials that have been used as a mixture to for solidification of peat.

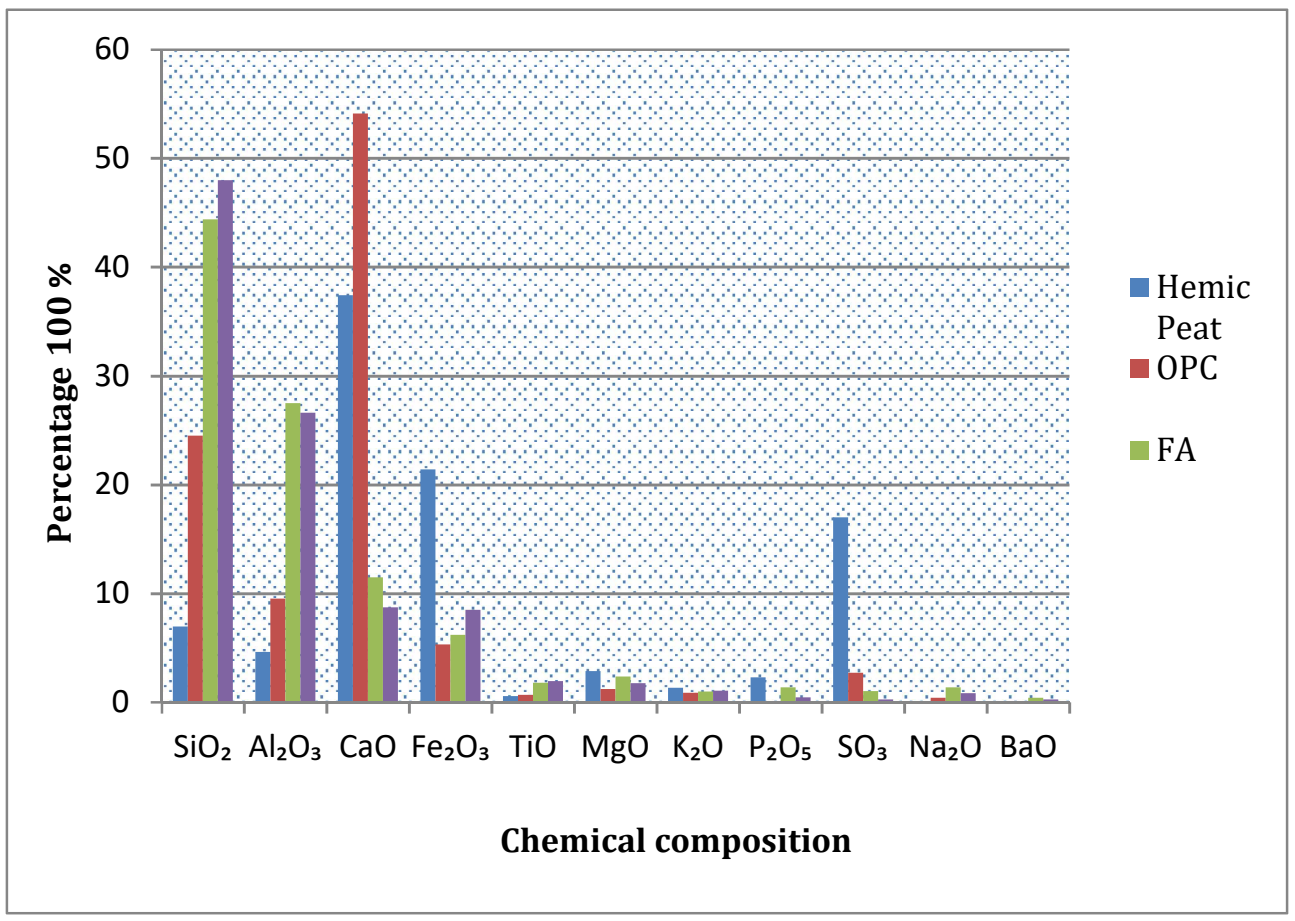

Fig. 2. XRF analysis results.

\subsection{Environmental Analysis of leachate}

\subsubsection{Anions leachate Analysis}

Figure 3 represents the anion analysis leachate from hemic peat in its natural condition before solidification and analysis leachate from solidified hemic peat after solidification. However, symbols of this study represent as $\mathrm{H}=$ natural hemic peat, $\mathrm{RW}=$ rainwater, $\mathrm{SP}=$ solidified peat which means $\mathrm{H}+\mathrm{RW}$ as a test before solidification, while $\mathrm{H}+\mathrm{RW}+\mathrm{SP}$ as test after solidification. Both of $\mathrm{H}+\mathrm{RW}$ and $\mathrm{H}+\mathrm{RW}+\mathrm{SP}$ are tested in wet and dry condition. In comparison with leachate concentration of anions for leachate of neutral hemic peat and leachate for solidified hemic peat, it is observed increasing for anions concentration at chloride $\left(\mathrm{Cl}^{-}\right)$and sulfate $\left(\mathrm{SO}_{4}{ }^{2-}\right)$. The concentration average of $\mathrm{Cl}^{-}$for $\mathrm{H}+\mathrm{RW}$ in wet condition is $4.776 \mathrm{mg} / \mathrm{L}$ and the concentration average of $\mathrm{Cl}^{-}$for $\mathrm{H}+\mathrm{RW}+\mathrm{SP}$ in wet condition is $38.94 \mathrm{mg} / \mathrm{L}$. The concentration average of $\mathrm{SO}_{4}{ }^{2-}$ for $\mathrm{H}+\mathrm{RW}$ in wet condition is $23.98 \mathrm{mg} / \mathrm{L}$ and the concentration average of $\mathrm{SO}_{4}{ }^{2-}$ for $\mathrm{H}+\mathrm{RW}+\mathrm{SP}$ in wet condition is $93.75 \mathrm{mg} / \mathrm{L}$. The concentration average of cation at phosphate $\left(\mathrm{PO}_{4}{ }^{3-}\right)$ after solidification 
was decreased. However, groundwater with $\mathrm{Cl}^{-}$concentration of less than $250 \mathrm{mg} / \mathrm{L}$ is classified as freshwater those having a higher concentration of chloride are considered brackish or saline [10]. Figure 3 summaries that increment of anions concentration for chloride and sulfate on the leachate of solidified hemic peat when solidified peat affected by rainwater. The increment of $\mathrm{Cl}^{-}$and $\mathrm{SO}_{4}{ }^{2-}$ concentration as result, the chemical composition of rainwater includes chloride and sulfate [11]. Therefore, the increment of anions concentration at $\mathrm{Cl}^{-}$and $\mathrm{SO}_{4}{ }^{2-}$ on the leachate at the wet season due to rainwater volume was increased during wet season compared to the quantity of rainwater during dry season and chemical composition of rainwater include chloride and sulfate.

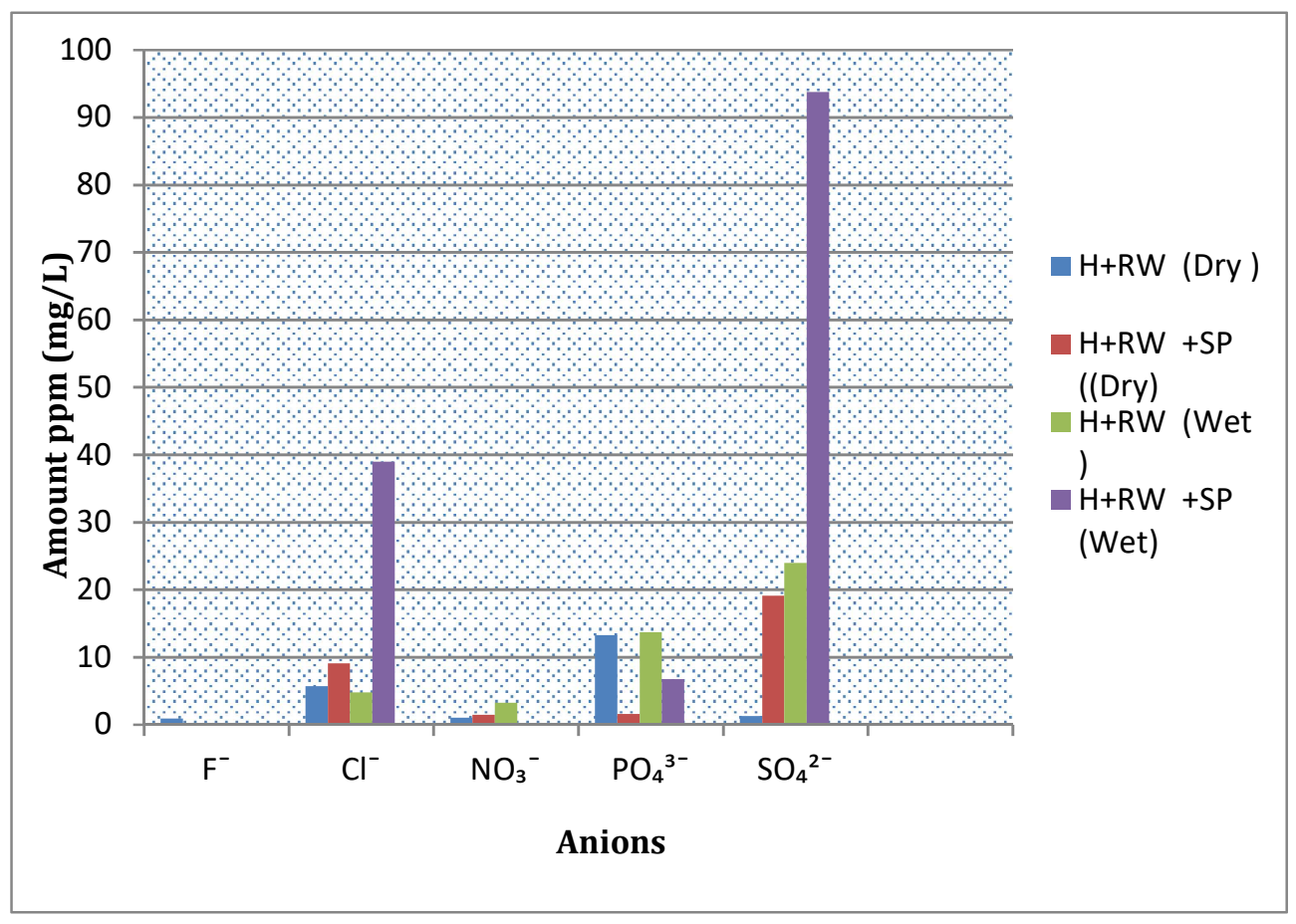

Fig. 3. The result of anions concentration on the leachate.

\subsubsection{Cations leachate Analysis}

Figure 4 shows the cations concentration on the leachate for copper cation $\left(\mathrm{Cu}^{+}\right)$ concentration average is $24.27 \mathrm{mg} / \mathrm{L}$ for hemic peat before solidified peat, while after solidified peat induced with rainwater concentration average is $32.23 \mathrm{mg} / \mathrm{L}$ in dry condition. In wet condition, $\mathrm{Cu}^{+}$concentration average is $43.2 \mathrm{mg} / \mathrm{L}$ for hemic peat before solidified peat, while after solidified induced with rainwater concentration average is $52.5 \mathrm{mg} / \mathrm{L}$. Fe $\mathrm{Fe}^{+2}$ concentration is increased after rainwater induced with solidified peat, where $\mathrm{Fe}^{+2}$ concentration average is $647 \mathrm{mg} / \mathrm{L}$ while after solidified peat is recorded as $710 \mathrm{mg} / \mathrm{L}$ in wet condition. In dry condition $\mathrm{Fe}^{+2}$ concentration average was for hemic peat leachate without solidification is $543.2 \mathrm{mg} / \mathrm{L}$ and $611.5 \mathrm{mg} / \mathrm{L}$ for leachate of solidified peat. The increments of $\mathrm{Fe}^{+2}$ concentration after solidified peat leachate due to solidification agents (OPC, FA, and BA) are including $\mathrm{Fe}_{2} \mathrm{O}_{3}$ that contribute to the addition of $\mathrm{Fe}^{+2}$ concentration. The increasing of iron concentration in the water is a factor behind brownification and watercolor is known to be affected also by the quality of organic matter and the prevalence of iron [12]. Iron (Fe) is a contributing factor to change watercolor, the contribution of $(\mathrm{Fe})$ to water brownification 
[15]. However, water brownification defined as freshwaters are a trend to change of watercolor where the water becomes increasingly browner [16]. $\mathrm{Al}^{+3}$ concentration on the leachate is increased after on leachate of solidified peat. The concentration average of $\mathrm{Al}^{+3}$ in wet condition was $376.2 \mathrm{mg} / \mathrm{L}$ for leachate of hemic peat without solidification while the concentration average of $\mathrm{Al}^{+3}$ for leachate of hemic peat after solidification is $431.7 \mathrm{mg} / \mathrm{L}$. By comparing between leachate concentrations of cations before solidified peat and after solidified of hemic peat, it observed increment of the concentration of $\mathrm{Al}^{+3}$ and $\mathrm{Fe}^{+2}$. Hence, the concentration of cations of leachate from solidified peat has increased at $\mathrm{Fe}^{+2}$ and $\mathrm{Al}^{+3}$ in wet condition, which proven solidified peat has an effect on the leachate by comparing with leachate of non-solidified peat.

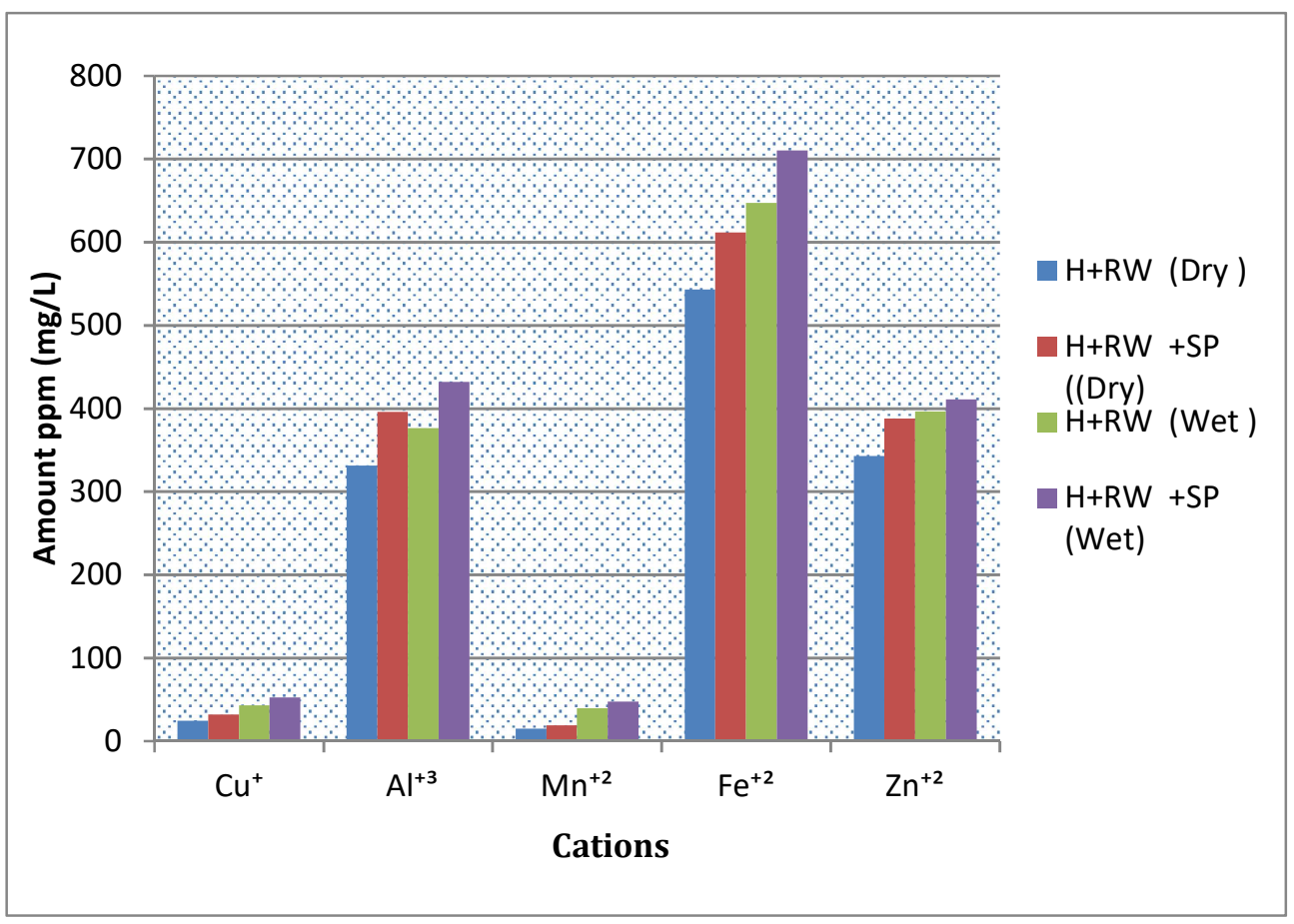

Fig. 4. The result of cations concentration on the leachate.

\section{Conclusion}

The concertation of anions and cations on the leachate during wet condition was increased more than dry condition due to the volume of rainwater quantity in the wet condition that helps rainwater effectively on the solidified peat more than the dry condition. The highest increase in concentration of anions after solidified were $\mathrm{SO}_{4}{ }^{2-}$ with average $93.75 \mathrm{mg} / \mathrm{L}$ and $\mathrm{Cl}^{-} 38.94 \mathrm{mg} / \mathrm{L}$. The increment of $\mathrm{Cl}^{-}$and $\mathrm{SO}_{4}{ }^{2-}$ concentration on leachate for the wet season as result rainwater inflow was increased during wet season and the chemical composition of rainwater contains $\mathrm{Cl}^{-}$and $\mathrm{SO}_{4}{ }^{2-}$. The increment of $\mathrm{Fe}^{+2}$ and $\mathrm{Al}^{+3}$ concentration after solidified peat leachate happens due to solidification agents $\mathrm{OPC}$, FA, and $\mathrm{BA}$ are containing $\mathrm{Fe}_{2} \mathrm{O}_{3}$ and $\mathrm{Al}_{2} \mathrm{O}_{3}$ that contribute to the addition of concentration of $\mathrm{Fe}^{+2}$ and $\mathrm{Al}^{+3}$, which proven solidified peat has an effect on the leachate by comparing with leachate of non-solidified peat. Through mixing by the formulation that has been used in this study, the concentration of cations at chloride and sulfate on the leachate still considers in the normal range of groundwater concentration that classified as freshwater. However, when FA, BA, and OPC 
are used excessively in the mixture for solidifying peat in a wetland, leachate from solidified peat will effect on the concentration of groundwater elements and land properties.

This study has been carried out with the financial support from FRGS 1574. Authors would like to thank all related parties including the research team, research center, and UTHM.

\section{References}

1. Said, Jasmin Binti Mohamad, and S. N. L. Taib. Peat stabilization with carbide lime. Diss. Universiti Malaysia Sarawak,2009.

2. Gatti, P., Bonardi, M., Tosi, L., Rizzetto, F., Fornasiero, A., Gambolati, G. \& Teatini, P. (2002). The Peat Deposit of the Subsiding Zennare Basin, South of the Venice Lagoon, Italy: Geotechnical Classification and Preliminary Mineralogical.

3. Huat, B. B., Kazemian, S., Prasad, A., \& Barghchi, M. (2011). State of an art review of peat: General perspective. International Journal of Physical Sciences, 6(8), 1988-1996.

4. Huat, B. B. K. (2002, July). Some mechanical properties of tropical peat and organic soils. In 2nd World Engineering Congress, Sarawak (pp. 82-87).

5. Wong, L. S., Hashim, R., \& Ali, F. H. (2009). A review on hydraulic conductivity and compressibility of peat. Journal of Applied Sciences, 9(18), 3207-3218.

6. Islam, M. S., \& Hashim, R. (2010). Stabilization of peat soil by soil-column technique and settlement of the group columns. International Journal of Physical Sciences, 5(9), 1411-1418.

7. American Society for Testing and Materials. Annual Book of ASTM Standards (1992). Philadelphia, PA. USA

8. Rahman, J. A., \& Chan, C. M. (2014). Effect of Additive to the Moisture Content at Different Decomposition Level of Peat. Journal of Civil Engineering Research, 4(3A), 59-62.

9. Kim, B., Prezzi, M., \& Salgado, R. (2005). Geotechnical properties of fly and bottom ash mixtures for use in highway embankments. Journal of Geotechnical and Geoenvironmental Engineering, 131(7), 914-924.

10. Samsudin, A. R., Hamzah, U., \& Rafek, A. G. (1997). Salinity study of coastal groundwater aquifers in North Kelantan, Malaysia.

11. Khoon, S. H., Issabayeva, G. I., \& Lee, L. W. (2011). Measurement of rainwater chemical composition in Malaysia based on ion chromatography method. World Academy of Science, Engineering, and Technology, 11, 161-168.

12. Kritzberg, E. S., \& Ekström, S. M. (2012). Increasing iron concentrations in surface waters-a factor behind brownification? Biogeosciences, 9(4), 1465.

13. Carlson, C. L., \& Adriano, D. C. (1993). Environmental impacts of coal combustion residues. Journal of Environmental Quality, 22(2), 227-247.

14. Adriano, D. C., Page, A. L., Elseewi, A. A., Chang, A. C., \& Straughan, I. (1980). Utilization and Disposal of Fly Ash and Other Coal Residues in Terrestrial Ecosystems: A Review 1. Journal of Environmental Quality, 9(3), 333-344.

15. Sarkkola, S., Nieminen, M., Koivusalo, H., Laurén, A., Kortelainen, P., Mattsson, T., ... \& Finér, L. (2013). Iron concentrations are increasing in surface waters from forested headwater catchments in eastern Finland. Science of the Total Environment, 463, 683689.

16. Graneli, W. (2012). Brownification of lakes. In Encyclopedia of lakes and reservoirs (pp. 117-119). Springer Netherlands. 